Volume 1 Issue 1, January-June 2020: pp.51-62.

Faculty of Law, Universitas Lampung, Bandar Lampung, Indonesia.

http://jurnal.fh.unila.ac.id/index.php/ip

P-ISSN: 2723-2638

E-ISSN: $2745-9314$

\title{
Eksekusi Pidana Denda Terhadap Pelaku Tindak Pidana Penjualan Barang Tanpa Dibubuhi Tanda Pelunasan Cukai
}

\author{
Criminal Execution of Fines Against the Criminal Actors of Sales of Goods \\ Without Signs of Exchange Refund
}

\author{
Ika Mutiara Putri \\ ikamutiaraputri@gmail.com \\ Kejaksaan Tinggi Lampung
}

Submitted: Mar 23, 2020; Reviewed: Apr 27, 2020; Accepted: Mei 16, 2020

\begin{tabular}{|c|c|}
\hline Info Artikel & Abstrak \\
\hline $\begin{array}{l}\text { Kata Kunci: Eksekusi; Pidana Denda; } \\
\text { Cukai. } \\
\text { Keywords: Execution; Criminal Fines; } \\
\text { Excise. }\end{array}$ & $\begin{array}{l}\text { Pidana denda subsidair kurungan yang } \\
\text { dijatuhkan oleh Majelis Hakim dijadikan celah } \\
\text { yang dimanfaatkan oleh terpidana untuk } \\
\text { terbebas dari kewajiban membayarkan denda. } \\
\text { Selain itu adanya kendala bagi Jaksa untuk } \\
\text { menerapkan eksekusi pidana denda, karena } \\
\text { pidana denda yang dijatuhkan oleh Majelis } \\
\text { Hakim tersebut bersifat subsidair atau dapat } \\
\text { diganti dengan kurungan badan. Permasalahan } \\
\text { penelitian ini dirumuskan: bagaimanakah praktik } \\
\text { eksekusi pidana denda terhadap pelaku tindak } \\
\text { pidana cukai yaitu penjualan barang tanpa } \\
\text { dibubuhi tanda pelunasan cukai. Pendekatan } \\
\text { yang digunakan adalah yuridis normatif serta } \\
\text { yuridis empiris. Data dikumpulkan melalui studi } \\
\text { kepustakaan dan studi lapangan, selanjutnya } \\
\text { dianalisis kualitatif. Sesuai dengan deskripsi } \\
\text { hasil penelitian menunjukkan bahwa: Praktik } \\
\text { eksekusi pidana denda terhadap pelaku tindak } \\
\text { pidana cukai yaitu penjualan barang tanpa } \\
\text { dibubuhi tanda pelunasan cukai dilaksanakan } \\
\text { oleh Kejaksaan Negeri Bandar Lampung setelah } \\
\text { menerima berkas salinan atas Putusan }\end{array}$ \\
\hline
\end{tabular}


pengadilan dari Panitera selambat-lambatnya satu minggu setelah putusan dibacakan. Selanjutnya Kepala Kejaksaan Negeri Bandar Lampung menerbitkan Surat Perintah Eksekusi Putusan Pengadilan yang memerintahkan Tim Jaksa untuk mengksekusi pidana denda terhadap terpidana cukai. Hasil eksekusi tersebut selanjutnya disusun dan dilaporkan ke dalam Berita Acara Eksekusi Putusan Pengadilan.

\section{Abstract}

Criminal penal subsidair imprisonment imposed by the panel of judges used as a gap that is used by the convicted person to be free from the obligation to pay fines. Besides that, there are obstacles for the prosecutor to implement the execution of criminal fines, because the criminal fines imposed by the panel of judges are subsidair or can be replaced with confinement bodies. The problem of this research is formulated: how is the practice of the execution of criminal fines against the prepetrators of excise crime, namely the sale of goods without the marking of excise payment. The approach used is normative juridicial and empirical juridicial. Data were collected through literature studies and field studies, then analyzed qualitatively. In accordance with the description of the results of the study shows that: The practice of the execution of fines against the perpetrators of excise criminal acts, namely the sale of goods without the marking of excise payment carried out by the Bandar Lampung District Attorney after receiving a copy of the court's decision from the Registrar no later than one week after the verdict was read. Furthermore, the Head of the Bandar Lampung District Prosecutor's Office issued a Court Decision Execution Order ordering the Prosecutors Team to execute a criminal fine against a convicted tax officer. The results of the execution are then compiled and reported in the Minutes of the Execution of Court Decisions. 


\section{A. Pendahuluan}

Cukai merupakan salah satu pungutan secara tidak langsung, cukai sebagaimana dimaksud Pasal 1 angka (1) Undang-Undang (UU) Nomor 39 Tahun 2007 tentang Perubahan Atas UU Nomor 11 Tahun 1995 tentang Cukai (UU Cukai), adalah sebagai pungutan yang dijalankan oleh negara terhadap barang-barang tertentu yang mempunyai beberapa karakteristik yaitu konsumsi barang tersebut perlu dikendalikan, peredaran barang perlu untuk diawasi, pemakaian barang mengakibatkan dampak negatif bagi masyarakat atau lingkungan hidup, dan pemakaian barang perlu pembebanan pungutan demi mewujudkan keadilan serta keseimbangan. Untuk itu prinsip dasar pemungutan cukai yang universal adalah terdapat pembatasan terhadap konsumsi suatu produk. ${ }^{1}$

Pemerintah memberlakukan UU Cukai sebagai upaya pembinaan dan pengaturan terhadap barang-barang tertentu yang mempunyai karakteristik khusus. Dalam hal ini kewajiban cukai hanya dibebankan bagi pihak yang diwajibkan dan seluruh pihak tersebut diperlakukan sama dengan kondisi yang sama pula, untuk penyelenggaraan pemerintah yang bertanggungjawab, diperlukan kemampuan dan kewenangan dalam menggali sumber-sumber keuangan. ${ }^{2}$ Hal ini memiliki kaitan dengan penerimaan yang diperoleh negara atas cukai tersebut yang nantinya akan dipergunakan untuk kepentingan negara serta untuk membiayai pembangunan. ${ }^{3}$

Pemerintah meskipun telah memberlakukan UU Cukai sebagai alat hukum yang bersifat mengikat, namun realitanya masih terjadi tindak pidana cukai yang telah diatur dan diancam pidana dalam Pasal 54 UU Cukai jo. Pasal 55 Ayat (1) Ke-1 Kitab Undang-Undang Hukum Pidana (KUHP). Amar putusan Majelis Hakim yang menjatuhkan pidana berupa denda subsidair kurungan dijadikan celah yang dimanfaatkan oleh terpidana untuk terbebas dari kewajiban membayarkan denda. Isu hukum lainnya nya adalah adanya kendala bagi Jaksa untuk menerapkan eksekusi pidana berupa denda, karena pidana berupa denda yang dijatuhkan oleh Majelis Hakim tersebut bersifat subsidair atau dapat diganti dengan kurungan badan. Jaksa dalam hal ini tidak dapat menempuh upaya paksa berupa penyitaan atau perampasan aset terpidana untuk membayarkan denda sebagaimana dimaksud dalam putusan Majelis Hakim. Hal ini menunjukkan bahwa realitasnya penerapan eksekusi tidak terlaksana dengan lancar, karena adanya berbagai hambatan yang ditemui, dengan demikian dapat mengganggu proses eksekusi oleh pihak Kejaksaan sesuai dengan tugasnya dan perannya. Eksekusi baru bisa dijalankan apabila Putusan Pengadilan Negeri (hakim) yang bersangkutan sudah tidak mungkin lagi diajukan upaya banding atau kasasi. ${ }^{4}$

Jaksa dalam sistem peradilan pidana mempunyai peran yang luas serta mencakup semua tahap penanganan dalam perkara pidana yaitu penanganan pada tahap penyidikan, penanganan pada tahap penuntutan, tahap pemeriksaan di suatu pengadilan, peran pada tahap upaya hukum dan peran pada tahap eksekusi putusan Majelis Hakim. ${ }^{5}$ Eksekusi adalah pelaksanaan Putusan Majelis Hakim yang telah mempunyai kekuatan hukum yang tetap dan mengikat. Putusan Majelis Hakim baru dapat dijalankan, jika telah mendapat kekuatan pasti, yaitu jika tidak ditempuh perbandingan setelah diucapkan Hakim di muka umum, terkecuali jika terdakwa mohon pertangguhan menjalankan putusan selama 14 hari dalam tempo mana

\footnotetext{
${ }^{1}$ Wisnu Nugrahini, "Pengaruh Kebijakan Tarif Dan Harga Jual Eceran Terhadap Produksi Dan Penerimaan Cukai Rokok Sigaret Kretek Mesin.” Jurnal Presfektif Bea dan Cukai. Vol. 1. No. 3. (2019). hlm. 115.

2 Dwiki Ananto Yudo, "Optimalisasi Pendapatan Asli Daerah (Pad) Di Dki Jakarta Melalui Cukai Kendaraan Bermotor." Jurnal Ilmu Manajemen dan Akutansi. Vol. 7. No.2. (2019). hlm. 140.

${ }^{3}$ Bambang Semedi. Tindak Pidana di Bidang Kepabeanan dan Cukai. Pusat Pendidikan dan Pelatihan Bea dan Cukai, Jakarta, 2009. hlm.14

${ }^{4}$ Sri Hartini, Setiati Widihastuti, dan Iffah Nurhayati. "Eksekusi putusan hakim dalam sengketa perdata di Pengadilan Negeri Sleman.” Jurnal Civics. Vol. 14. No. 2. (2017).

${ }^{5}$ Marwan Effendy, Kejaksaan Republik Indonesia, Posisi dan Fungsinya dari Perspektif Hukum. Ghalia Indonesia. 2007. hlm. 66.
} 
terhukum memajukan permohonan grasi pada Presiden. Biasanya putusan dapat dijalankan terhadap tertuduh hanya setelah putusan tadi dijadikan putusan paling akhir dengan perkataan lainnya jika upaya-upaya hukum yang biasa telah ditempuh. ${ }^{6}$

Eksekusi Putusan Majelis Hakim yang telah memperoleh kekuatan hukum yang tetap diterapkan oleh pihak Kejaksaan, setelah Penitera menyampaikan salinan surat putusan bagi jaksa yang telah diatur pada Pasal 270 Kitab Undang-Undang Hukum Acara Pidana (KUHAP). ${ }^{7}$ Eksekusi Putusan Majelis Hakim baru dapat diterapkan oleh pihak Kejaksaan, setelah pihak jaksa menerima berkas salinan surat putusan dari panitera, dengan limit waktu penyampaian salinan atas Putusan dari Panitera bagi jaksa untuk perkara acara biasa selambat-lambatnya 1 (satu) minggu dan untuk perkara dengan acara singkat selambatlambatnya 14 hari. $^{8}$

Permasalahan yang diajukan dalam penelitian ini dirumuskan: Bagaimanakah praktik eksekusi pidana berupa denda terhadap pelaku tindak pidana cukai yaitu penjualan barang tanpa dibubuhi tanda pelunasan cukai? Pendekatan yang digunakan adalah yuridis normatif serta yuridis empiris. Analisis data dilakukan dengan analisis kualitatif untuk memperoleh simpulan sesuai dengan permasalahan yang dibahas.

\section{B. Pembahasan}

Hukum merupakan kesepakatan antar manusia yang memiliki manfaat berdasarkan rasionalitas dan perasaan manusia. Kemanfaatan bagi manusia menjadi latar belakang terciptanya suatu hukum. Dengan kata lain hukum tidak akan diciptakan untuk tujuan yang buruk, kecuali ada penyalahgunaan kewenangan oleh penguasa dan mencampurkan adukan hukum dengan politik demi kepentingan pribadi atau golongan tertentu. ${ }^{9}$ Eksekusi sebagai proses tahapan paling akhir penyelesaian perkara dalam sistem peradilan pidana yang dianut KUHAP. Hukum acara pidana berfungsi mencari dan menemukan kebenaran pemberian putusan Majelis Hakim serta eksekusi Putusan Majelis Hakim. Adapun fungsi mencari dan menemukan kebenaran kemudian dijalankan melalui persidangan di Pengadilan sesuai hukum acara dan sesuai dengan hasil persidangan tersebut hakim memberi putusan yang selanjutnya akan dilakukan eksekusi oleh pihak Kejaksaan. Demikian pula halnya dengan tindak pidana penjualan barang tanpa dibubuhi tanda pelunasan cukai.

Pengaturan mengenai tindak pidana penjualan barang tanpa dibubuhi tanda pelunasan cukai ada dalam Pasal 54 UU Cukai dan diancam pidana dengan pidana berupa penjara paling singkat 1 tahun dan selambat-lambatnya 5 tahun dan/atau pidana berupa denda paling sedikit 2 kali nilai cukai dan paling banyak 10 kali nilai cukai yang seharusnya dibayar. Pengaturan pidana berupa denda dalam Pasal 54 UU Cukai dijalankan dengan mengakumulasi ancaman pidana berupa denda dengan ancaman pidana berupa penjara. Dengan demikian terhadap pelaku kejahatan cukai yang melanggar pasal yang didalamnya telah diatur secara komulatif pidana berupa denda dan pidana berupa penjara, dengan demikian dapat Majelis Hakim harus memutuskan pidana berupa denda dan penjara secara bersamaan. Dalam rangka melakukan pengawasan terhadap sarana pengangkut, pejabat bea cukai diberikan wewenang untuk melakukan pemeriksaan atas sarana pengangkut. Pemeriksaan sarana pengangkut tersebut bertujuan untuk menjamin hak-hak negara dan dipatuhinya ketentuan dibidang kepabeanan

\footnotetext{
${ }^{6}$ P.A.F. Lamintang dan Theo Lamintang, Pembahasan KUHAP Menurut Ilmu Pengetahuan Hukum Pidana \& Yurisprudensi,Sinar Grafika, Jakarta , 2010, hlm.7

${ }^{7}$ Ibid. hlm.7.

${ }^{8}$ Andi Hamzah. Hukum Acara Pidana Indonesia. Sinar Grafika Offset, Jakarta, 2009.hlm.14

${ }^{9}$ Shandi Patria Airlangga, "Hakikat Penguasa Dalam Negara Hukum Demokratis," Cepalo 3, no. 1 (September 17, 2019): 110, https://doi.org/10.25041/cepalo.v3no1.1783. hlm 6.
} 
dan ketentuan lain yang pelaksanaannya dilakukan oleh bea cukai. Karena apabila hal-hal tersebut tidak dipatuhi maka akan ada sanksi atau ancaman pidanya. ${ }^{10}$

Bahwa ancaman pidana berupa denda yang cukup tinggi yang dikumulatifkan dengan pidana berupa penjara dalam UU Cukai menunjukan bahwa perkara cukai adalah perkara yang sangat signifikan, dengan demikian dapat perlu diberi pengancaman pidana yang berat yang tidak hanya penjara tetapi juga denda bagi pelaku kejahatan cukai. Pidana berupa denda mempunyai tujuan atau manfaat yaitu memberi keuntungan bagi keuangan negara karena memberi pendapatan negara. ${ }^{11}$ Selain itu dengan dijatuhkannya pidana berupa denda yaitu sebagai solusi permasalahan kelebihan kapasitas lapas dan memberi efek jera bagi pelaku kejahatan cukai. Melalui pidana berupa denda, maka negara memperoleh uang pendapatan negara dan mendapat solusi mengenai beban negara pada permasalahan kelebihan volume lapas. Apabila kita melihat Pasal 112 Undang-Undang No. 17 Tahun 2006 Tentang Kepabeanan maka, memberikan peran khusus kepada penyidik dari lingkungan bea cukai untuk memberantas tindak pidana penyelundupan. Maka pada saat ini bila terjadi tindak pidana di bidang kepabeanan yang salah satunya adalah tindak pidana penyelundupan maka yurisdiksi Undang-Undang yang diterapkan adalah Undang-Undang No. 17 Tahun 2006 Tentang Kepabean. ${ }^{12}$ Kemudian jika ditinjau dari perspektif pelaku kejahatan cukai, pidana berupa denda akan membuat pelaku jera dan mencegah melakukan kejahatan lagi atau mencegah agar tidak melakukan kejahatan yang lebih lagi.

Ancaman pidana berupa denda yang telah diatur pada UU Cukai bersifat kumulatif dengan pidana berupa penjara, sehingga pelaku kejahatan cukai yang melanggar pasal yang di dalamnya diatur secara kumulatif pidana berupa penjara dan pidana berupa denda, Majelis Hakim harus memutuskan pidana berupa denda dan pidana berupa penjara secara bersamasama. Pidana berupa denda pada perkara cukai dalam kasus di Pengadilan Negeri Tanjung Karang memiliki tujuan untuk menjatuhkan pidana lebih berat. Hal ini mengindikasikan tindak pidana cukai adalah perkara yang signifikan, hingga perlu diberi ancaman pidana yang berat, yang tidak hanya penjara tetapi juga denda. Ancaman pidana yang dikumulatifkan dengan pidana berupa penjara memang untuk menjatuhkan pidana lebih berat bagi pelaku kejahatan cukai. Hal ini dimaksudkan untuk memberi dan memberi jaminan rasa keadilan bagi masyarakat sebagaimana yang dituju oleh penjatuhan hukuman. Kemudian pejabat bea dan cukai dalam melkaukan pengawasan kemudian menemukan suatu pelanggaran maka dilakukan penindakan untuk menyelesaikan pelanggaran tersebut, apabila pelanggaran itu merupakan tindak pidana maka akan dilakukan penyidikan dan pemberian sanksi pidana, sedangkan untuk pelanggaran administrasi maka dikenakan sanski administrasi. ${ }^{13}$

Pidana berupa denda sebagai sarana untuk meraih tujuan pidana sebagai salah satu jenis pidana pokok yang telah diatur pada Pasal 10 KUHP yang meliputi hukuman mati, penjara, kurungan, dan denda; dan pidana tambahan berupa pencabutan beberapa hak hak tertentu, perampasan barang tertentu, dan pengumuman putusan Majelis Hakim. Putusan hakim harus mencerminkan tiga unsur tujan hukum yakni keadilan, kepastian hukum, dan manfaat, hal ini seperti yang dikemukakan oleh Gustav Radbruch sehingga akan menopang dimensi aksiologis. ${ }^{14}$ Kemudian di dalam proses perkembangan putusan hakim, pidana berupa denda

\footnotetext{
${ }^{10}$ Ikramulla Syarifuddin, Mustaring, Dan Andi Kasmawati. "Peranan Direktorat Jenderal Bea Dan Cukai Dalam Mencegah Peredaran Narkoba Di Parepare." Jurnal Tomalebbi (Jurnal Pemikiran, Penelitian Hukum, Pendidikan Pancasila dan Kewarganegaraan. Vol. V. No. 1. (2018). Hlm. 101.

${ }^{11}$ Hasila wawancara dengan Sri Aprilinda Dani selaku Jaksa pada Kejaksaan Tinggi Lampung. Kamis 16 Januari 2020.

12 Jessica E. Saroinsong, "Peran Penyidik Pegawai Negeri Sipil (Ppns) Dalam Tindak Pidana Bea Dan Cukai Menurut Undang-Undang No. 17 Tahun 2006 Tentang Kepabeanan Dalam Kasus Penyelundupan.” Jurnal Lex Et Societatis. Vol. Vii. No. 7 (2019).

13 Raelma Meisyelha, "Tinjauan Yuridis Terhadap Pelanggaran Kepabeanan Di Kawasan Perbatasan.” Jurnal Lex Et Societatis. Vol. VIII. No. 1. (2020).

${ }^{14}$ Nur Agus Susanto, “Dimensi Aksiologis Dari Putusan Kasus "St”." Jurnal Yudisial. Vol. 7. No.3 (2014).
} 
sebagai alternatif pidana telah diakomodasi oleh negara sebagai politik kriminal. Hal ini tercermin dari banyaknya peraturan perundang-undangan yang juga mencantumkan pidana berupa denda sabagai hukuman, bahkan dalam Rancangan KUHP ancaman pidana berupa denda hampir ada pada ancaman pidana pada setiap pasal yang mengatur tentang kejahatan.

Jaksa sebagai pihak yang melaksanakan putusan Majelis Hakim yang telah mempunyai kekuatan hukum yang tetap tersebut dituntut memiliki kemampuan teknis yang profesional dalam menerapkan tugas dan kewenangannya sebagai eksekutor sesuai dengan ketentuan. Sesuai Pasal 1 butir 11 KUHAP, yang dimaksud Putusan Majelis Hakim ialah pernyataan hakim yang diucapkan dalam suatu pengadilan terbuka, yang dapat berupa pidana atau bebas atau lepas dari segala tuntutan hukum, dalam hal serta menurut cara yang telah diatur pada undang-undang. Putusan Majelis Hakim dapat dilakukan eksekusi jika putusan telah memiliki kekuatan hukum tetap. Pengertian putusan yang telah memiliki kekuatan hukum yang tetap adalah jika terdakwa ataupun penuntut umum telah menerima putusan, jika upaya hukum tidak digunakan oleh pihak yang berhak, sehingga masa tenggang waktu untuk mengajukan upaya hukum tersebut habis. Upaya hukum telah diajukan oleh pihak berhak, tetapi lalu upaya hukum yang telah diajukan lalu dicabut dan Putusan Mahkamah Agung (MA) dalam pemeriksaan untuk Kasasi.

Kejaksaan dalam menjalankan atau menerapkan Putusan Majelis Hakim dan penetapan hakim memperhatikan norma serta nilai yang hidup dalam masyarakat dan perikemanusiaan sesuai dengan Pancasila tanpa mengenyampingkan sikap ketegasan. Menurut Pasal 270 KUHAP panitera pengadilan menyampaikan salinan atas Putusan Majelis Hakim yang memiliki kekuatan hukum tetap dan in kracht. ${ }^{15}$ untuk dilaksanakan oleh pihak Kejaksaan. KUHAP tidak mengatur dalam jangka waktu berapa lama panitera menyampaikan salinan atas Putusan bagi Jaksa. MA memberi batas jangka waktu pengiriman, ialah dalam surat Edaran MA Nomor 21 Tahun 1983 tanggal 8 Desember 1983, panitera diwajibkan menyampaikan salinan atas Putusan bagi Jaksa selambat-lambatnya 1 minggu untuk perkara Acara Pemeriksaan Biasa (APB) dan selambat-lambatnya 14 hari untuk perkara Acara Pemeriksaan Singkat (APS). Dalam hal putusan MA karena telah mempunyai kekuatan hukum yang tetap, jaksa dapat mengeksekusi cukup dengan petikan putusan, tanpa menunggu salinan atas Putusan.

M. Randi Alkaisa ${ }^{16}$ memaparkan bahwa kejahatan cukai dijalankan bermotif ekonomi dan umumnya mempunyai tujuan untuk memperoleh harta kekayaan yang sebanyakbanyaknya. Logikanya adalah harta kekayaan bagi pelaku kejahatan sebagai darah yang menghidupi kejahatan, dengan demikian dapat cara yang paling efektif untuk memberantas dan mencegah terhadap kejahatan dengan motif ekonomi adalah dengan memutus alur kehidupan dari kejahatan dengan cara merampas hasil dan intrumen kejahatan tersebut. Argumentasi tersebut tidak mengecilkan arti hukuman pidana badan terhadap pelaku kejahatan cukai. Harus diakui bahwa sekedar menjatuhkan pidana badan terbukti tidak mengakibatkan efek jera bagi pelaku kejahatan cukai. Konstruksi sistem hukum pidana memiliki tujuan untuk mengungkap kejahatan yang terjadi, menemukan pelakunya serta menghukum pelaku kejahatan cukai dengan hukuman, terutama pidana badan baik pidana berupa penjara ataupun kurungan. Sementara itu, isu pengembangan hukum dalam lingkup internasional seperti masalah penyitaan dan perampasan hasil kejahatan dan alat kejahatan belum dijadikan bagian yang penting di dalam sistem hukum pidana di Indonesia. ${ }^{17}$

Penjatuhan pidana tersebut hakikatnya sebagai suatu bentuk penebusan atas kesalahan oleh pelaku kejahatan, namun demikian ada bentuk penebusan lainnya berupa mengganti

\footnotetext{
15 Hani Irham Dessetya, Pujiyono, Bambang Dwi Baskoro. "Eksekusi Barang Bukti Pada Perkara Ilegal Logging Dipengadilan Negeri Semarang." Jurnal Diponegoro Law Review. Vol. 1. No. 4. (2014).

${ }^{16}$ Hasila wawancara dengan M. Randi Alkaisa selaku Jaksa pada Kejaksaan Negeri Bandar Lampung. Selasa 14 Januari 2020.

17 Juhaya S. Praja, Teori Hukum dan Aplikasinya, Pustaka Setia, Bandung, 2011, hlm.9
} 
kerugian material akibat dari kejahatan. Konteks tersebut menunjukkan bahwa keadilan restorasi sebagai rangkaian proses peradilan yang hakikatnya memiliki tujuan untuk memulihkan kembali kerugian material yang diderita oleh korban dari kejahatan. Keadilan restoratif memiliki tujuan untuk merestorasi atau memulihkan kembali suatu keadaan seperti sebelum terjadi kejahatan.

Pidana memberikan kesempatan untuk melakukan perubahan atau penyesuaian pidana bagi terpidana. Pelaku yang dijatuhi pidana atau tindakan yang telah mempunyai kekuatan hukum yang tetap dapat diimplementasikan perubahan atau penyesuaian dengan mengingat perkembangan terpidana dan tujuan pidana. Aparat penegak hukum menerapkan fungsinya dalam sistem peradilan pidana untuk melakukan penanggulangan suatu kejahatan, dengan tujuan mencegah masyarakat dijadikan korban dari kejahatan, menyelesaikan kasus kejahatan yang terjadi, dengan demikian dapat masyarakat puas bahwa keadilan telah ditegakkan dan yang bersalah dipidana dan mengusahakan mereka yang pernah melakukan kejahatan tidak mengulangi lagi kejahatannya.

Hakikatnya eksekusi Putusan Majelis Hakim diatur pada Bab XIX Pasal 270 sampai Pasal 276 KUHAP. Putusan Majelis Hakim yang dilakukan eksekusi sebagai Putusan Majelis Hakim yang telah memperoleh kekuatan hukum yang tetap (Inkracht van gewijsde). Menurut teoritik dan praktik suatu Putusan Majelis Hakim telah mempunyai kekuatan hukum yang tetap jika terdakwa dan penuntut umum telah menerima putusan sebagaimana dinyatakan dalam "surat pernyataan menerima putusan" jika upaya tidak dipergunakan, dengan demikian dapat tenggang waktunya terlampaui, jika diajukan permohonan banding lalu dicabut kembali dan adanya permohonan grasi yang diajukan disertai permohonan penangguhan eksekusi.

Petikan Putusan Majelis Hakim dapat dijadikan dasar mengksekusi terhadap terpidana. Setelah hakim memutus perkara umumnya dilakukan proses minutasi dan selama proses minutasi ini penyelesaian minutasi perkara bisa dipercepat dan tidak harus menunggu sampai 7 bahkan 14 hari, cukup dengan waktu paling lama 3 hari berkas perkara yang sudah diputus bisa selesai diminutasi oleh Pengadilan, kemudian bagi para pihak diberikan petikan putusan. ${ }^{18}$ Petikan putusan memuat amar yang diputuskan Majelis Hakim. Berbekal petikan putusan pun sebenarnya jaksa telah dapat mengksekusi putusan yang telah mempunyai kekuatan hukum yang tetap. Petikan putusan telah dapat dijadikan dasar eksekusi. Persoalan eksekusi perkara pidana sebagai kewenangan lembaga Kejaksaan. Jika salinan atas Putusan atau petikan putusan (pidana) telah dikirimkan bagi para pihak (terdakwa dan kejaksaan), itu bukan kewenangan pengadilan lagi, tetapi kewenangan Kejaksaan.

Petikan putusan pidana telah dapat dijadikan dasar eksekusi, sebab di dalamnya ada amar/diktum putusan, tetapi pertimbangan hukumnya belum dimuat. Jika suatu perkara telah diputus dan salinan atas Putusannya dalam proses minutasi, petikan putusan segera dikirim ke para pihak. Praktik eksekusi pidana berupa denda terhadap pelaku tindak pidana cukai yaitu penjualan barang tanpa dibubuhi tanda pelunasan cukai dilaksanakan oleh Kejaksaan Negeri Bandar Lampung setelah menerima berkas salinan atas Putusan Majelis Hakim dari Panitera Pengadilan Negeri Tanjung Karang selambat-lambatnya satu minggu setelah putusan dibacakan. Selanjutnya Kepala Kejaksaan Negeri Bandar Lampung menerbitkan Surat Perintah Eksekusi Putusan Majelis Hakim yang memerintahkan Tim Jaksa untuk mengksekusi pidana berupa denda terhadap terpidana cukai. Hasil eksekusi tersebut selanjutnya disusun dan dilaporkan ke dalam Berita Acara Eksekusi Putusan Majelis Hakim.

Rangkaian prosedur eksekusi Putusan Majelis Hakim yang telah mempunyai kekuatan hukum yang tetap dilaksanakan oleh pihak Kejaksaan (Pasal 270 KUHAP, Pasal 33 Ayat (1) UU Kejaksaan, Pasal 27 Ayat (1) huruf b Kejaksaan dengan mempergunakan sarana

\footnotetext{
18 Khoirun Nisa, Eva Hany Fanida. "Penerapan Sistem Informasi Administrasi Perkara Pegadilan Agama (Siadpaplus) Melalui Aplikasi Audio To Text Recording Di Pengadilan Agama Kabupaten Malang." Jurnal Publika (Administrasi Negara) Unesa. Vol.4. No. 5. (2016).
} 
administrasi berupa surat perintah eksekusi Putusan Majelis Hakim (P-48), Berita Acara eksekusi Putusan Majelis Hakim (BA-8), butir 14 Kepmenkeh Nomor M-14.PW.07.03 Tahun 1983 dan Surat Jampidum Nomor B-235/E/3/1994 tanggal 4 Maret 1994 Perihal Eksekusi Putusan Majelis Hakim. ${ }^{19}$

Eksekusi Putusan pidana denda tidak terpisahkan dengan eksekusi Putusan pidana badan serta pembayaran biaya perkara. Pidana berupa denda dikenakan terhadap pasal-pasal yang ada ancaman dendanya. Pada umumnya kejahatan tertentu dalam KUHP tidak memakai ancaman denda dan dalam prakteknya kini tidak pernah diterapkan denda sesuai dengan pasal-pasal KUHP. Putusan denda pada umumnya dikenakan terhadap pasal-pasal undangundang tertentu di luar KUHP. Pada umumnya dalam Undang-Undang tertentu di luar KUHP, pidana berupa denda dapat menyertai pidana badan atau komulatif namun ada juga yang diterapkan menggantikan pidana badan atau alternatif, bahwa besarnya jumlah pidana berupa denda yang dijatuhkan Majelis Hakim dijadikan hambatan dalam eksekusi Putusan Majelis Hakim atau kejahatan penjualan barang tanpa dibubuhi tanda pelunasan cukai dilaksanakan oleh Kejaksaan Negeri Bandar Lampung, karena terpidana tidak memiliki kemampuan untuk membayarkan denda.

Majelis Hakim dalam perkara cukai ketika memutuskan pidana berupa denda mempertimbangkan berbagai hal, diantaranya adalah jumlah dan jenis barang bukti, kondisi perekonomian pelaku kejahatan cukai, peran pelaku kejahatan cukai, residivis, hasil kejahatan, pendapat masyarakat, dan tuntutan jaksa. Pada pertimbangan jumlah dan jenis barang bukti, semua Majelis Hakim dalam hal ini menyatakan bahwa jumlah dan jenis barang bukti yang ada pada kasus tersebut mempengaruhi besar denda yang dijatuhkan. Semakin besar jumlah barang bukti semakin besar jumlah denda yang dijatuhkan. Para Majelis Hakim juga setuju bahwa kondisi perekonomian pelaku kejahatan cukai dijadikan pertimbangan dalam menetapkan jumlah denda yang dijatuhkan. Jika kondisi yang dijatuhkan ringan, disesuaikan dengan kondisi perekonomian. Peran pelaku kejahatan cukai dalam melakukan kejahatan dijadikan hal signifikan dalam pertimbangan Majelis Hakim. Faktor residivis juga dijadikan bahan pertimbangan lainnya, dan jika pelaku kejahatan cukai seorang residivis dijadikan pertimbangan Majelis Hakim untuk memutuskan denda lebih tinggi. Residivis adalah orang yang pernah dihukum mengulangi tindak kejahatan yang serupa, penjahat karnbuhan, terdakwa yang pernah dijatuhi hukuman dua tahun. ${ }^{20}$ Kemudian mengenai tindak pidana yang dilakukan dan soal siapa yang menikmati hasil kejahatan, maka penikmatan hasil kejahatan dijadikan hasil pertimbangan dalam memutuskan denda yang dijatuhkan. Selainnya itu jika masyarakat memandang perbuatan pelaku kejahatan cukai sangat meresahkan dan merugikan masyarakat maka akan menjatuhkan pertimbangan denda. Sebagian lainnya pula menyatakan bahwa jumlah tuntutan jaksa dijadikan pertimbangan dalam penjatuhan pidana berupa denda. Penjelasan di atas menunjukkan bahwa yang dijadikan dasar pertimbangan dalam menetapkan jumlah denda adalah sebagian besar dari pelaku kejahatan cukai dan selain pelaku kejahatan cukai.

Majelis Hakim juga mengakui bahwa kondisi perekonomian masyarakat yang rendah dan rasa keadilan masyarakat mempengaruhi putusan Majelis Hakim. Hal ini diakui sebagai kendala utama para Majelis Hakim dalam penjatuhan pidana berupa denda, sebab nominal pidana denda dalam KUHP yang tidak mengikuti laju perekonomian bangsa, membuat pidana denda tidak efektif. ${ }^{21}$ Kondisi perekonomian masyarakat yang rendah memang sangat mempengaruhi pembayaran pidana berupa denda. UU Cukai memang telah mengatur

\footnotetext{
${ }^{19}$ Ruddy Handoko. "Tinjauan Yuridis Kasasi Terhadap Putusan Bebas Dalam Sistem Pemidanaan Di Indonesia.” Jurnal Spektrum Hukum, Vol. 15. No. 2. (2018).

${ }^{20}$ Anggi Anggraenil, Sugiarti dan Mellia Christia. "Gambaran Seif.Tsteeivi Pada Petaku Residivisme: Studi Pada Residivis Di Tembaga Pemasyarakatan Ktas I Cipinanc.” Indigenous: Jurnal Ilmiah Psikologi. Vol. 5 No. 1. (2020).

${ }^{21}$ Muhammad Iftar Aryaputra, Ani Triwati, dan Subaidah Ratna Juita. "Kebijakan Aplikatif Penjatuhan Pidana Denda Pasca Keluarnya Perma No. 2 Tahun.” Jurnal Dinamika Sosial Budaya. Vol. 19. No. 1. (2017).
} 
ancaman berupa pidana berupa denda, bahkan dengan ancaman yang cukup tinggi, akan tetapi ketika Majelis Hakim merasa dan dasar pertimbangan perekonomian bahwa terpidana tidak dapat membayarkan denda, maka denda atasnya dijatuhkan lebih ringan., dengan demikian dapat untuk penanggulangan kejahatan cukai mengingat pelaku yang diajukan ke pengadilan kebanyakan perekonomian lemah, maka pidana berupa penjara masih sebagai hukuman yang utama, sedangkan pidana berupa denda sebagai pidana tambahan saja. Selain itu, kendala lainnya yang dirasakan oleh Majelis Hakim dalam menerapkan pidana berupa denda yaitu undang-undang tidak mengatur ancaman berupa pidana berupa denda, dimana pidana denda tidak ada ketentuan maksimum umumnya. Kedua pasal tersebut hanya mengatur ketentuan maksimum umum dan minimum umum dalam KUHP, kemudian maksimum khususnya terdapat dalam pasal-pasalnya tanpa mengatur minimum khususnya. Ketentuan maksimum umum dalam KUHP untuk pidana penjara adalah selama 15 (lima belas) tahun berturut-turut dan untuk pidana kurungan selama 1 (satu) tahun sedangkan ketentuan mengenai minimum umum dalam KUHP untuk pidana penjara adalah selama 1 (satu) tahun dan untuk pidana kurungan adalah selama 1 (satu) hari. Pengaturan sistem minimum, maksimum umum, dan khusus serta sistem minimum khusus, maka hakim dalam menjatuhkan pidana dapat bergerak antara pidana yang tertinggi dan yang paling rendah. ${ }^{22}$

Mengenai rasa keadilan masyarakat yang juga dianggap kendala dalam penerapan pidana berupa denda, maksudnya adalah karena denda dianggap bukan sebagai hukuman yang juga memberi efek jera, maka tetap saja fokus pemindaan dimata masyarakat adalah pidana berupa penjara. Jadi, walaupun pidana telah dijatuhkan tinggi yang mana konsekuensinya tentu saja pidana berupa penjara seharusnya tidak lagi terlalu tinggi, atau bahkan jika perumusan ancaman secara alternatif, tetap saja pidana berupa penjara harus diterapkan. Mengingat besarnya denda yang hampir tidak mungkin dapat dibayar oleh terpidana maka pimpinan memberi himbauan bagi para Jaksa dalam bentuk Surat Kepala Kejaksaan Tinggi bagi seluruh Kepala Kejaksaan Negeri di wilayahnya agar para Jaksa selalu membuat surat Pernyataan tentang kesanggupan/ketidaksanggupan terpidana dalam membayarkan dalam penanganan perkara yang memuat putusan pidana berupa denda tersebut.

Model ideal eksekusi pidana berupa denda terhadap pelaku tindak pidana cukai yaitu penjualan barang tanpa dibubuhi tanda pelunasan cukai pada masa yang akan datang dapat dilaksanakan dengan melakukan pembenahan dalam tiga bidang, yaitu bidang penegak hukum, bidang peraturan, dan bidang masyarakat. Pembenahan pada bidang penegak hukum dapat dilaksanakan dengan peningkatan profesionalisme Majelis Hakim, karena Majelis Hakim yang memiliki peran menetapkan penjatuhan hukuman, dan mereka pula yang secara langsung melihat bagaimana keadaan di lapangan, dengan demikian Majelis Hakim mampu menilai pidana yang tepat untuk dijatuhkan. Selain itu keterlibatan aparatur Negara dan aparatur hukum atau pembiaran terhadap pelanggaran hukum/tidak ditaatinya perlu diberikan sanksi yang sesuai. ${ }^{23}$ Peraturan perundang-undangan yang dilakukan Peraturan perundangundangan adalah statis dan masyarakat adalah dinamis, dengan demikian dapat seorang aparat penegak hukum harus professional untuk mempersatukan peraturan dan kondisi masyarakat, dengan demikian dapat menghasilkan suatu putusan yang adil, berguna dan mempunyai kepastian hukum. Upaya peningkatan profesionalisme Majelis Hakim dapat menerapkan dengan pendidikan baik formil ataupun non formil. Pendidikan formil antara lainnya adalah memberi kesempatan bagi Majelis Hakim untuk melanjutkan pendidikan ke jenjang yang lebih tinggi, misalnya program magister atau program doktor. Sedangkan pendidikan nonformil dapat diterapkan melalui pelatihan seminar mengenai pidana berupa denda juga

\footnotetext{
${ }^{22}$ Oheo K. Haris, "Telaah Yuridis Penerapan Sanksi Di Bawah Minimum Khusus Pada Perkara Pidana Khusus.” Jurnal Ius Constituendum. Vol.2. No. 2. (2017). hlm.246.

${ }^{23}$ Muhar Junef, "Penerapan Sanksi Adat Kepada Perusahaan Dan Pihak Lain Dalam Peradilan Adat." E-Journal Widya Yustisia. Vol. 1 No. 2. (2015). Hlm.105.
} 
pelatihan terpadu Majelis Hakim mengenai pidana, dengan demikian dapat mempunyai kesamaan persepsi terhadap pidana berupa denda. Selain itu peningkatan profesionalisme memalui jalur pendidikan juga dapat dijalankan melalui studi banding mengenai penerapan pidana berupa denda ke negara-negara yang telah lama menerapkan pidana berupa denda dan penerapan tersebut telah berjalan efektif. Penelitian ini untuk mempelajari hal-hal apa yang dijadikan kendala dan bagaimana cara mengatasinya, dan dapat dengan mengetahui hal tersebut dapat di aplikasikan sesuai dengan kondisi yang terjadi di Indonesia.

Kemampuan aparat penegak hukum perlu diperhatikan untuk mengefektifkan penerapan pidana berupa denda, dengan demikian dapat tujuan pidana tersebut dapat tercapai, Pidana perlu mempertimbangkan sistem penetapan jumlah atau besarnya pidana berupa denda, limit waktu penerapan pembayaran denda, tindakan-tindakan paksaan yang diharapkan dapat memberi jaminan terlaksananya pembayaran denda dalam hal ini terpidana tidak membayar dalam limit waktu yang telah ditetapkan.

\section{Penutup}

Praktik eksekusi pidana denda terhadap pelaku tindak pidana cukai yaitu penjualan barang tanpa dibubuhi tanda pelunasan cukai dilaksanakan oleh Kejaksaan Negeri Bandar Lampung setelah menerima berkas salinan atas Putusan Majelis Hakim dari Panitera Pengadilan Negeri selambat-lambatnya satu minggu setelah putusan dibacakan. Selanjutnya Kepala Kejaksaan Negeri Bandar Lampung menerbitkan Surat Perintah Eksekusi Putusan Majelis Hakim yang memerintahkan Tim Jaksa untuk mengksekusi pidana berupa denda terhadap terpidana cukai. Hasil eksekusi tersebut selanjutnya disusun dan dilaporkan ke dalam Berita Acara Eksekusi Putusan Majelis Hakim.

\section{Daftar Pustaka}

A. Buku

Effendy, Marwan. 2007. Kejaksaan Republik Indonesia, Posisi dan Fungsinya dari Perspektif Hukum. Ghalia Indonesia. Jakarta.

Hamzah, Andi. 2009. Hukum Acara Pidana Indonesia. Sinar Grafika Offset, Jakarta.

Lamintang, P.A.F. dan Theo Lamintang, 2010. Pembahasan KUHAP Menurut Ilmu Pengetahuan Hukum Pidana \& Yurisprudensi, Sinar Grafika, Jakarta.

Praja, Juhaya S. 2011. Teori Hukum dan Aplikasinya, Pustaka Setia, Bandung.

Semedi, Bambang. 2009. Tindak Pidana di Bidang Kepabeanan dan Cukai. Pusat Pendidikan dan Pelatihan Bea dan Cukai, Jakarta.

B. Jurnal

Airlangga, Shandi Patria. "Hakikat Penguasa Dalam Negara Hukum Demokratis." Cepalo 3, no. 1, September 17, 2019: 1-10. https://doi.org/10.25041/cepalo.v3no1.1783. https://jurnal.fh.unila.ac.id/index.php/cepalo/article/view/1783/1487

Anggi Anggraenil, S. d. "Gambaran Seif.Tsteeivi Pada Petaku Residivisme: Studi Pada Residivis Di Tembaga Pemasyarakatan Ktas I Cipinanc.". Indigenous: Jurnal Ilmiah Psikologi. Vol. 5 No. $\quad 1, \quad 2020: \quad 115-125$, http://journals.ums.ac.id/index.php/indigenous/article/view/4750/3138. https://doi.org/10.23917/indigenous.v0i0.4750.

Handoko, R. "Tinjauan Yuridis Kasasi Terhadap Putusan Bebas Dalam Sistem Pemidanaan Di Indonesia." Jurnal Spektrum Hukum, Vol. 15. No. 2, 2018: 238-235. http://203.89.29.50/index.php/SH/article/view/1118/965. http://dx.doi.org/10.35973/sh.v15i2.1118

Hani Irham Dessetya, P. B. "Eksekusi Barang Bukti Pada Perkara Ilegal Logging Dipengadilan Negeri Semarang." Jurnal Diponegoro Law Review. Vol. 1. No. 4, 2014. https://ejournal3.undip.ac.id/index.php/dlr/article/view/1012/1028. 
Haris., O. K. "Telaah Yuridis Penerapan Sanksi Di Bawah Minimum Khusus Pada Perkara Pidana Khusus." Jurnal Ius Constituendum. Vol.2. No. 2., 2017: 246. http://journals.usm.ac.id/index.php/jic/article/view/663/427. http://dx.doi.org/10.26623/jic.v2i2.663.

Ikramulla Syarifuddin, M. D. "Peranan Direktorat Jenderal Bea Dan Cukai Dalam Mencegah Peredaran Narkoba Di Parepare." Jurnal Tomalebbi (Jurnal Pemikiran, Penelitian Hukum, Pendidikan Pancasila dan Kewarganegaraan. Vol. V. No. 1, 2018. https://ojs.unm.ac.id/tomalebbi/article/view/6768/3878.

Junef, M. "Penerapan Sanksi Adat Kepada Perusahaan Dan Pihak Lain Dalam Peradilan Adat." E-Journal Widya Yustisia. Vol. 1 No. 2, $2015: 105$. https://media.neliti.com/media/publications/247133-penerapan-sanksi-adat-kepadaperusahaan-b60892a9.pdf.

Khoirun Nisa, E. H. "Penerapan Sistem Informasi Administrasi Perkara Pegadilan Agama (Siadpaplus) Melalui Aplikasi Audio To Text Recording Di Pengadilan Agama Kabupaten Malang." Jurnal Publika (Administrasi Negara) Unesa. Vol.4. No. 5, 2016.

Muhammad Iftar Aryaputra, A. T. "Kebijakan Aplikatif Penjatuhan Pidana Denda Pasca Keluarnya Perma No. 2 Tahun." Jurnal Dinamika Sosial Budaya. Vol. 19. No. 1, 2017: 5671. http://journals.usm.ac.id/index.php/jdsb/article/view/685/440. http://dx.doi.org/10.26623/jdsb.v19i1.685.

Nugrahini, W. "Pengaruh Kebijakan Tarif Dan Harga Jual Eceran Terhadap Produksi Dan Penerimaan Cukai Rokok Sigaret Kretek Mesin." Jurnal Presfektif Bea dan Cukai Vol. 1. No. 3., 2019: 115. http://jurnal.pknstan.ac.id/index.php/PBC/article/view/426/293. http://dx.doi.org/10.31092/jpbc.v3i1.426.

Raelma Meisyelha. "Tinjauan Yuridis Terhadap Pelanggaran Kepabeanan Di Kawasan Perbatasan." Jurnal Lex Et Societatis. Vol. VIII. No. 1, 2020. https://ejournal.unsrat.ac.id/index.php/lexetsocietatis/article/viewFile/28480/27833.

Saroinsong, J. E. "Peran Penyidik Pegawai Negeri Sipil (Ppns) Dalam Tindak Pidana Bea Dan Cukai Menurut Undang-Undang No. 17 Tahun 2006 Tentang Kepabeanan Dalam Kasus Penyelundupan." Jurnal Lex Et Societatis. Vol. Vii. No. 7, 2019. https://ejournal.unsrat.ac.id/index.php/lexetsocietatis/article/view/26839.

Sri Hartini, S. W. "Eksekusi putusan hakim dalam sengketa perdata di Pengadilan Negeri Sleman." Jurnal Civics. Vol. $14 . \quad$ No. $2,2017$. https://journal.uny.ac.id/index.php/civics/article/view/16852/pdf. https://doi.org/10.21831/civics.v14i2.16852.

Susanto, N. A. "Dimensi Aksiologis Dari Putusan Kasus "St"." Jurnal Yudisial. Vol. 7. No.3, 2014. https://jurnal.komisiyudisial.go.id/index.php/jy/article/view/73/57. http://dx.doi.org/10.29123/jy.v7i3.73.

Yudo, D. A. "Optimalisasi Pendapatan Asli Daerah (Pad) Di Dki Jakarta Melalui Cukai Kendaraan Bermotor." Jurnal Ilmu Manajemen dan Akutansi. Vol. 7. No.2, 2019: 140. https://jurnal.unitri.ac.id/index.php/refrensi/article/view/1493/pdf. https://dx.doi.org/10.33366/ref.v7i2.1493. 
